DOI: https://doi.org/10.47405/mjssh.v5i1.351

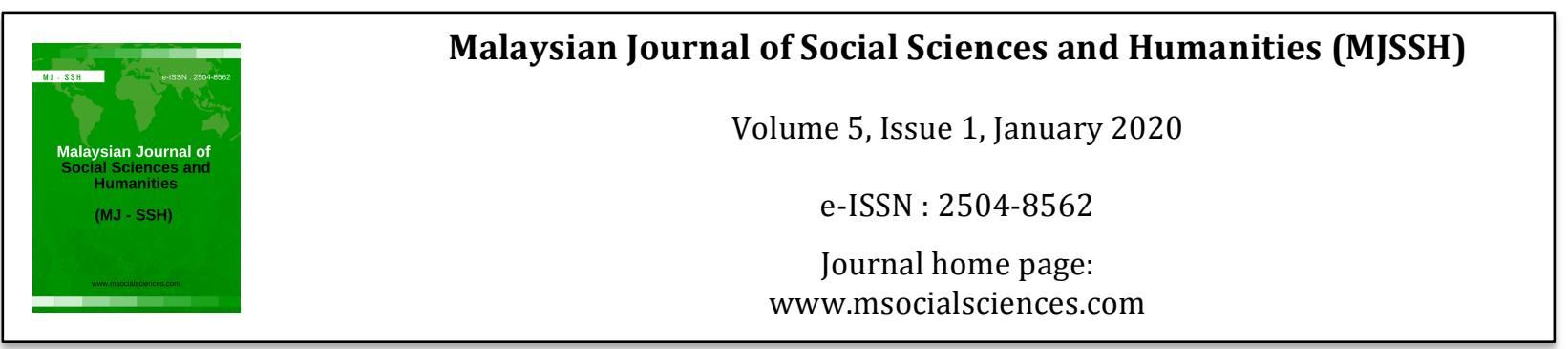

\title{
Pola Kunjungan Pelancongan Keluarga Berasaskan Aktiviti Sebelum, Semasa dan Selepas ke Pantai Pelancongan Pulau: Pantai Chenang Langkawi
}

\author{
Nurul Fadhliah Muhamad Din', Habibah Ahmad', Hamzah Jusoh'1, Kadaruddin Aiyub1 \\ ${ }_{1}^{1}$ Fakulti Sains Sosial dan Kemanusiaan, Universiti Kebangsaan Malaysia (UKM) \\ Correspondence: Habibah Ahmad (ha@ukm.edu.my)
}

\begin{abstract}
Abstrak
Pantai pelancongan Cenang sering menjadi tumpuan pelancong kerana daya tarikan alam semulajadi pantai dan kemudahan pembangunan di sekitarnya. Oleh sebab itu, kedua-dua buah destinasi tersebut tetap menjadi salah satu kunjungan wajib para pelancong terutamanya pelancong keluarga untuk bercuti dan lari daripada kesibukan ibu kota. Trend aktiviti pelancongan pantai ini semakin berterusan berikutan peningkatan permintaan terhadap alam semulajadi dalam kalangan penduduk berkeluarga di bandar-bandar besar terutamanya di negara-negara Eropah dan Barat. Malaysia juga tidak terkecuali. Makalah ini bertujuan untuk mengenalpasti cirian dan pola kunjungan berdasarkan segmen pelancong keluarga domestik ke Pantai Chenang, Pulau Langkawi. Kajian ini dijalankan melalui kaedah kuantitatif iaitu menggunakan borang soal selidik yang diedarkan di sekitar Pantai Chenang. Teknik pensampelan secara kebetulan digunakan bagi sampel kajian dan sebanyak 350 borang soal selidik yang telah mendapat maklum balas daripada pelancong keluarga domestik yang berada di sekitar Pantai Chenang. Hasil analisis menunjukkan tidak terdapat perbezaan yang ketara dalam setiap aktiviti yang dilakukan mengikut segmen cirian pelancong keluarga yang berkunjung. Pelancong keluarga menunjukkan bahawa setiap aktiviti yang dilakukan oleh mereka melibatkan kesemua ahli keluarga dan memainkan peranan masing-masing tidak kira sebelum ke pantai, semasa di pantai sehinggalah pulang dari pantai.
\end{abstract}

Kata kunci: pantai pelancongan, pelancong keluarga, Pantai Chenang Langkawi

\section{Patterns of Family-Travel Based on Before, During and After Activities to the Island's Tourist Beaches at Pantai Chenang, Langkawi}

\begin{abstract}
Pantai Chenang is often a tourist attraction due to the natural beauty of the beach and its surrounding development facilities. Therefore, both these destinations remains one must visit tourist travelers especially for family vacation and get away from the bustle of the capital. he trend of beach tourism activity is continuing due to the increasing demand for nature among families in major cities, especially in European and Western countries. Malaysia is no exception. This paper aims to identify and mark the pattern of family visits by domestic tourists segment to Pantai Chenang, Pulau Langkawi. This study was conducted by quantitative method. A total of 350 questionnaire forms were obtained from domestic family tourists around Pantai Chenang using incidental sampling techniques. The analysis showed that there was no significant difference in each activity performed according to the segment of the visiting family. Family travelers show that every activity they perform involves all the family members and plays their part regardless of the beach, while at the beach until returning from the beach.
\end{abstract}


Keywords: beach tourism, family travelers, Pantai Chenang Langkawi

\section{Pengenalan}

Pantai sentiasa menjadi kunci kepada pembangunan ekonomi negara sejak dari dahulu lagi bahkan potensi industri berasaskan pantai ini juga mampu memberi impak kepada kepelbagaian industri lain di Malaysia mahupun di luar negara. Pelancongan pantai merupakan satu sektor yang semakin berkembang pesat dewasa ini sama ada di negara maju mahupun di negara-negara membangun. Menurut Honey \& Krantz (2007) pelancongan pantai antara salah satu sektor pelancongan yang terbesar dalam industri pelancongan global dan juga merupakan salah satu pelancongan alternatif yang kian popular terutamanya dalam kalangan pelancong keluarga tempatan hari ini. Trend ini dijangka berterusan berikutan peningkatan permintaan yang tinggi terhadap alam semulajadi seperti air laut, pasir dan matahari dalam kalangan penduduk berkeluarga di bandar-bandar besar terutamanya di negara-negara Eropah dan Asia (Honey \& Vargas 2007).

Kawasan pesisir pantai adalah sangat penting sebagai sebuah destinasi pelancongan kerana ianya mampu menyumbang kepada peningkatan ekonomi negara (Gosh \& Datta 2012). Manakala menurut Sahoo (2014) pula berpendapat bahawa pelancongan yang berasaskan alam semulajadi pantai ini juga cenderung untuk menjana dan menampung jumlah pelancong yang banyak serta dapat memberi pengalaman baru kepada pelancong (SIT-Special Interest Tourism). Perkembangan ini semakin jelas ketara, apabila pembangunan pantai-pantai pelancongan telah bertambah meluas dengan tumpuan kepada kawasan peranginan yang mempunyai iklim sinaran matahari yang banyak (United Nations 2016). Peningkatan lawatan ke pantai-pantai pelancongan semakin bertambah apabila tibanya cuti hujung minggu atau musim cuti yang panjang. Ianya terus berkembang dengan adanya penyediaan sepenuhnya tempat-tempat penginapan yang menarik dan unik seperti hotel, resort, kemudahan tempat makan, hiburan dan infrastruktur (Wong 2009). Jika dahulu pantai hanya dikunjungi kerana keindahan alam semulajadi, namun kini kunjungan ke pantai pelancongan telah menjadi satu 'trend' percutian yang wajib.

Melihat tingginya potensi pantai dalam sektor pelancongan terutamanya di dalam kalangan pelancong keluarga, justeru, bagi terus menarik dan mengekalkan kunjungan pelancong keluarga untuk terus datang berkunjung ke pantai-pantai pelancongan sebagai sebuah destinasi pelancongan seisi keluarga, satu pendekatan baru wajar diterokai secara lebih menyeluruh bagi menjamin keperluan, aspirasi dan tuntutan serta memberi pengalaman maksimum kepada mereka antaranya melalui pelancongan pantai mesra keluarga. Namun begitu, walaupun semakin dikenali dengan kepesatan kunjungan pelancongpelancong tempatan dan luar negara, ia juga masih baru dalam konteks pembangunan dan penyelidikan di Malaysia terutamanya mengikut segmen pelancong keluarga. Bagi mempromosikan pantai sebagai sebuah produk pelancongan yang mesra keluarga, pantai pelancongan itu sendiri hendaklah mempunyai identiti yang tersendiri, menarik dan unik.

Menurut Nazrin et al. (2014) kejayaan sesebuah destinasi pelancongan dan persaingan dalam menarik pelancong menuntut sesebuah destinasi itu menawarkan pakej pelancongan yang terbaik, unik dan kreatif, yang mampu memenuhi keperluan dan memberi kepuasan serta pengalaman maksimum kepada pelancong. Pelancong cenderung bertindak balas terhadap sesebuah tarikan yang mesra pelancong antaranya kemudahan dan perkhidmatan mudah digunakan tanpa gangguan (Swarbrooke 1995). Umumnya, pelancongan merupakan satu pendekatan yang kolektif, dimana ianya mengetengahkan pelancong sebagai pelanggan utama (Anuar et. al 2012). Hampir $70 \%$ pelancong yang melancong mempunyai tujuan-tujuan tertentu dan mereka merupakan subjek yang utama dalam memajukan industri pelancongan (Khospakyants \& Vidisheva 2010).

Pantai Chenang Pulau Langkawi merupakan salah satu pantai pelancongan tumpuan pelancong. Menerusi laporan Blueprint Pelancongan Langkawi (2011-2015), Pantai Chenang telah dinobatkan sebagai destinasi pilihan keluarga untuk berhibur. Selain memberi kesan yang positif keatas 
pembangunan ekonomi negara, peningkatan kehadiran pelancong keluarga domestik ke pantai pelancongan Chenang ini juga telah banyak membantu dan mengembangkan pasaran ekonomi masyarakat setempat. Pelancongan berorientasikan keluarga adalah salah satu pasaran terbesar dan paling berterusan untuk industri pelancongan namun penyelidikan pelancongan jarang mengambil perhatian tentang pengalaman percutian keluarga (Carr 2011; Obrador 2012). Untuk menjamin kehadiran pelancong keluarga ke pantai pelancongan, pelbagai isu berkaitan dengan pelancongan pantai harus diberi perhatian. Ini tidak terkecuali bagi isu cirian pelancong keluarga terhadap destinasi pelancongan pantai. Ini kerana, hampir separuh waktu cuti yang dibuat oleh keluarga dan kanak-kanak adalah melibatkan aktiviti pelancongan di pantai dan air (Aderhold 2003).

Di Malaysia, kajian mengenai segmen keluarga secara mendalam terhadap aktiviti pelancongan pantai ini amat terhad dan tidak jelas. Selain itu, mekanisme cirian pelancong yang melancong ke pantaipantai pelancongan juga dilihat masih kabur dan tiada data terperinci tentang kehadiran dan aktiviti mereka. Kebanyakkan kajian yang bersifat akademik tidak menyentuh secara langsung tentang cirian aktiviti pelancong keluarga. Kebanyakan kajian lebih banyak memberi tumpuan terhadap imej destinasi, kedudukan destinasi pelancongan, personaliti destinasi pelancongan, jenama destinasi, destinasi berdaya saing, analisis destinasi pelancongan pilihan, atribut dan produk destinasi pelancongan, faktor yang mempengaruhi pelancongan dan penilaian destinasi pelancongan (Azzopardi \& Nash 2013; Baker \& Crompton 2000; Botha et al. 1999; Chen \& Phou 2013; Hsu et al. 2009; Kastenholz et al. 2013; Mohamadkhani \& Barezani 2013; Mutinda \& Mayaka 2012). Walau bagaimanapun, tidak terdapat bukti empirik yang wujud menjelaskan mekanisme cirian tersebut. Pencirian kehadiran pelancong keluarga serta corak aktiviti mereka merupakan panduan dalam perkembangan pelancongan pantai. Lanjutan daripada itu, adakah wujud atau tiada perbezaan setiap aktiviti yang dilakukan antara segmen pelancong keluarga?

Sehubungan dengan itu, berasaskan kepentingan dalam membangunkan pelancongan pantai mesra keluarga, langkah awal dalam mengenal pasti perspektif pola kunjungan pelancong keluarga terhadap pantai pelancongan adalah relevan dan wajar satu kajian dilakukan untuk membangunkan pelancongan pantai mesra keluarga ini dari perspektif pelancong keluarga. Oleh itu, artikel ini bertujuan untuk mengenal pasti cirian kunjungan pelancong keluarga di Pantai Chenang Pulau Langkawi melalui tiga situasi yang berbeza iaitu sebelum kepantai, semasa di pantai dan selepas ke pantai. Dengan intipati yang diperolehi, makalah ini dapat menyumbang kepada usaha mempromosi serta memperkasakan lagi pantai pelancongan menerusi pandangan pelancong keluarga kepada pelancong keluarga yang lain.

\section{Pelancongan Pantai}

Pantai merupakan salah satu lokasi percutian yang menjadi pilihan dan tumpuan masyarakat pada masa kini (Johan et al. 2012). Menurut Orams, M (1999) telah memperincikan definisi pelancongan pantai yang melibatkan pergerakan keluar manusia dari tempat tinggal ke destinasi yang mempunyai persekitaran pantai dengan aktiviti yang dijalankan bukan sahaja bertumpu di laut seperti menaiki kapal layar, selam skuba dan memancing, malahan termasuk juga aktiviti-aktiviti yang dijalankan di persisir pantai seperti mandi manda, membina istana pasir dan sebagainya. Bagi Ecori (2013) pula, pelancongan pantai merujuk kepada beberapa aktiviti pelancongan yang berasaskan ruang daratan dan lautan (pantai) seperti berenang, mandi manda dan aktiviti rekreasi di sekitar pesisiran pantai termasuklah perkhidmatan-perkhidmatan yang berkaitan.

Pantai dilihat sebagai sebuah tempat pelarian bagi masyarakat kota yang sentiasa sibuk dengan kehidupan harian untuk mencari ketenangan dan kedamaian. Pantai juga dijadikan sebagai tempat perkumpulan keluarga dengan ahli keluarga yang lain ataupun kumpulan kenalan terdekat untuk berkelah dan berinteraksi selain mengeratkan hubungan sesama manusia (Lascurain 1987). Pemilihan pantai bagi tujuan pelancongan ataupun untuk melakukan aktiviti utama yang lain seperti berehat merupakan satu strategi untuk memperkenalkan ekopelancongan kepada masyarakat. Biasanya sumber tarikan tersebut adalah dari segi sumber fizikal yang wujud di pantai seperti air lautnya, pasir pantai serta tumbuh tumbuhan, nilai rekreasi, saintifik dan nilai budaya (Syafrina, Ibrahim \& Joy 2000). Mengikut dapatan kajian Sufahani et al. (2013) dalam penyelidikannya yang bertajuk "An Analysis Of 
International Tourist Behaviour Toward Tourism Sector In Kelantan" menyatakan secara semulajadi negeri yang mempunyai sektor pelancongan pantai serta kecantikkan semulajadi berpotensi dan boleh dibangunkan sebagai sumber tarikan pelancongan utama kepada masyarakat umum iaitu dikenali sebagai pelancongan pantai.

\section{Pelancong Keluarga}

Umumnya bentuk sesuatu percutian adalah dipengaruhi oleh ciri-ciri keluarga, struktur dan fungsian keluarga tersebut. Ini termasuklah jenis, latar sosio-demografi, ekonomi dan saiz keluarga (Guiliono 1997). Di negara barat United Kigdom (UK) penglibatan ahli keluarga bersama kanak-kanak merupakan antara pelancong yang paling tinggi jumlahnya berbanding dengan jenis isi rumah yang lain (Beioley 2004) iaitu setanding dengan negara barat yang lain. Manakala di New Zealand pula, hanya $26 \%$ sahaja penglibatan pelancong atau penduduk yang berumur atas 18 tahun dan selebihnya hanyalah kanak-kanak di bawah jagaan ahli keluarga. Oleh itu, tidak hairanlah bahawa pelancong keluarga telah dikenalpasti sebagai sebuah isi rumah yang terbesar dalam melakukan perjalanan pelancongan di seluruh dunia (Shaw et al. 2008).

Menurut Yesawich (2007) pelancong keluarga melibatkan orang dewasa, termasuklah nenek datuk dan anak-anak. Dalam kajian The American Humourist Nathaniel Benchley (2001) terdapat dua jenis kelas perjalanan pelancongan keluarga iaitu kelas pertama (tanpa gangguan iaitu melibatkan ibu dan ayah sahaja) dan kelas bersama anak-anak (merujuk kepada beban perjalanan dengan anak-anak), hasil menunjukkan percutian bersama anak-anak mencatat jumlah yang paling tinggi berbanding percutian tanpa anak. Pelancong keluarga merujuk kepada sekumpulan masyarakat atau individu yang melancong atau bercuti bersama keluarga mereka sama ada dalam kalangan pelancong keluarga kecil/asas atau pelancong keluarga besar (Shaw 1997).

Selain itu, pelancong keluarga ini juga dapat dikategorikan dalam beberapa jenis sama ada keluarga melayu, keluarga cina, keluarga desa dan lain-lain (Habibah 2007; Habibah dan Hamzah 2012). Pelancong keluarga kecil adalah merujuk kepada ahli keluarga yang terdiri daripada ibu ayah dan anakanak sahaja, manakala pelancong keluarga besar pula melibatkan keluarga kecil, datuk, nenek dan gabungan beberapa keluarga asas yang lain seperti saudara mara, sepupu, ipar duai dan rakan sebaya. Menurut Maria dan Flavio (2013) pelancong keluarga merupakan satu unit biologi dan sosial yang mana semua aktiviti sosial, ekonomi, perlindungan dan kasih sayang dipupuk dan dinikmati oleh semua ahli dalam unit tersebut. Malahan jenis-jenis keluarga seperti keluarga muda, keluarga dewasa dan keluarga tua juga mempengaruhi jauh dan dekatnya pelancongan tersebut.

\section{Metod Kajian}

Kajiselidik dilaksanakan berperingkat iaitu melalui keadah membentuk soal-selidik, menentukan kawasan kajian, menentukan jumlah responden dan akhir sekali tatacara persampelan (Habibah, 2007). Kajian ini dilakukan ke atas pelancong keluarga domestik di Pantai Chenang, Pulau Langkawi. Soal selidik dirangka untuk mendapatkan perspektif dan penilaian pelancong keluarga mengenai penarafan pantai pelancongan yang mesra keluarga di pantai pelancongan Chenang.

Sampel yang digunakan adalah seramai 350 responden dengan menggunakan Teknik Persampelan Secara Kebetulan (convenience sampling). Set soalan mempunyai 3 bahagian. Bahagian pertama adalah demografi pelancong keluarga, bahagian kedua merupakan cirian kunjungan pelancong ke pantai pelancongan dan bahagian ketiga meliputi aktiviti-aktiviti yang dilakukan oleh pelancong keluarga di pantai pelancongan. Data daripada borang soal selidik dianalisis dan diproses melibatkan frekuensi, serta peratusan dan analisis diskriptif crosstab bagi hubungan antara klasifikafi bentuk keluarga dengan komponen kajian melalui perisian Statistic Package for Social Science (SPSS) Version 22.0. Hasil kajian rintis menggunakan analisis Cronbach Alpha bagi semua konstruk adalah berada di tahap kebolehpercayaan yang tinggi iaitu di antara 0.856 hingga 0.965 . 


\section{Kawasan Kajian}

Kawasan kajian yang dipilih adalah Pantai Chenang, Pulau Langkawi yang terletak 18.4 kilometer dari Pekan Kuah dengan anggaran 15 minit jarak perjalanan dari Lapangan Terbang Antarabangsa Langkawi. Pantai Chenang merupakan lokasi paling ramai dikunjungi kerana segala kemudahan seperti restoran, hotel serta chalet bajet, pusat hiburan dan kedai cenderamata mudah ditemui di sepanjang lokasi ini. Berdasarkan Rancangan Kawasan Khas Pantai Chenang 2015 (RKK Pantai Chenang 2015), Pantai Chenang antara destinasi pelancongan pantai yang mempunyai koridor mengunjur sepanjang 2.2 $\mathrm{km}$. Malah menurut Narimah (2010) Pantai Chenang antara destination-mix di Langkawi yang menawarkan keindahan semulajadi pantai tropika sebagai produk utama pelancongan. Pantai Chenang merupakan kawasan yang menjadi tarikan pelabur berikutan taburan pelancongnya yang tinggi berbanding kawasan-kawasan lain di sekitar Pulau Langkawi. Hal ini turut memberi kesan yang positif kepada pembangunan di Pulau Langkawi dan meningkatkan permintaan dalam pelbagai aspek dari tahun ke tahun.

\section{Hasil Kajian}

\section{Profil Pelancong}

Berdasarkan jadual 1 , jelas menunjukkan keluarga asas mencatat jumlah kunjungan yang paling tinggi iaitu sebanyak $74.4 \%$ iaitu di dalam kalangan keluarga asas penuh $70.1 \%$. Mengikut tempoh perkahwinan pula, keluarga pertengahan (5-20 tahun) adalah paling tinggi iaitu 82.6\% berbanding jenis keluarga yang lain. Hampir separuh keluarga yang mempunyai anak di bawah 17 tahun adalah paling ramai berkunjung iaitu 49.9\%. Manakala dari segi keluarga mengikut pendapatan pula, pendapatan dari Rm1000 dan keatas mencatat nilai peratusan yang sama tinggi iaitu di dalam kalangan keluarga yang bekerja kerajaan. Hampir separuh responden adalah dari kalangan pelancong keluarga melayu iaitu sebanyak $74.9 \%$.

Jadual 1: Profil pelancong

\begin{tabular}{llll}
\hline Komponen & Kategori & Bilangan & Peratus \\
\hline Bentuk keluarga I & Keluarga asas & 261 & 74.4 \\
& Keluarga luasan & 89 & 25.4 \\
Bentuk keluarga II & Keluarga asas separa penuh & 15 & 4.3 \\
& $\begin{array}{l}\text { Keluarga asas penuh } \\
\text { Keluarga luasan saudara }\end{array}$ & 246 & 70.1 \\
& mara/ipar/adikberadik & 25.4 \\
& & & \\
Jenis keluarga & Keluarga muda I (>5) & 23 & 6.6 \\
& Keluarga pertengahan (5-20) & 290 & 82.6 \\
& Keluarga matang (<20) & 37 & 10.5 \\
Keluarga mengikut umur & & \\
anak & Keluarga anak >10 tahun & 23 & 6.6 \\
& Keluarga anak $>17$ tahun & 175 & 49.9 \\
& Keluarga anak remaja/belia & 63 & 17.9 \\
& Keluarga anak dewasa/berkahwin & 89 & 25.4 \\
Penempatan & Keluarga bandar & 194 & 55.4 \\
& Keluarga luar bandar & 156 & 44.6 \\
Pendapatan & RM1000 ke bawah & 9 & 2.57 \\
& RM1000-RM2000 & 111 & 31.71 \\
& RM1000-RM3000 & 123 & 35.15 \\
\hline
\end{tabular}


DOI: https://doi.org/10.47405/mjssh.v5i1.351

\begin{tabular}{llll}
\hline & RM3001 ke atas & 107 & 30.57 \\
$\begin{array}{l}\text { Keluarga mengikut } \\
\text { bangsa }\end{array}$ & Keluarga Melayu & 262 & 74.9 \\
& Keluarga Cina & 88 & 25.1 \\
& Keluarga India & 0 & 0 \\
& Keluarga lain-lain & 0 & 0 \\
$\begin{array}{l}\text { Keluarga mengikut sektor } \\
\text { pekerjaan }\end{array}$ & Sektor kerajaan & 123 & 35.1 \\
& Sektor swasta & 100 & 28.6 \\
\hline
\end{tabular}

\section{Sebelum Ke Pantai}

\section{Tujuan dan rangsangan ke pantai}

Terdapat lima tujuan utama pelancong memilih untuk berkunjung ka Pantai Pelancongan Chenang. Setiap cirian pelancong keluarga yang berkunjung mempunyai tujuan yang berbeza. Bagi keluarga asas mahupun keluarga luasan, mereka mementingkan tujuan kekeluargaan untuk berehat, bermesra dan meraikan kejayaan ahli keluarga. Mereka juga bercuti untuk bermain sukan air dan tukar angin. Namun begitu, terdapat juga pelancong keluarga datang bercuti kerana lokasi pantai pelancongan dekat dengan kawasan kediaman mereka. Rata-rata pelancong keluarga sudah mengenali Pantai Chenang sebagai sebuah pantai pelancongan, jadi tujuan utama untuk mengenali destinasi adalah rendah jika dibandingkan dengan tujuan utama yang lain.

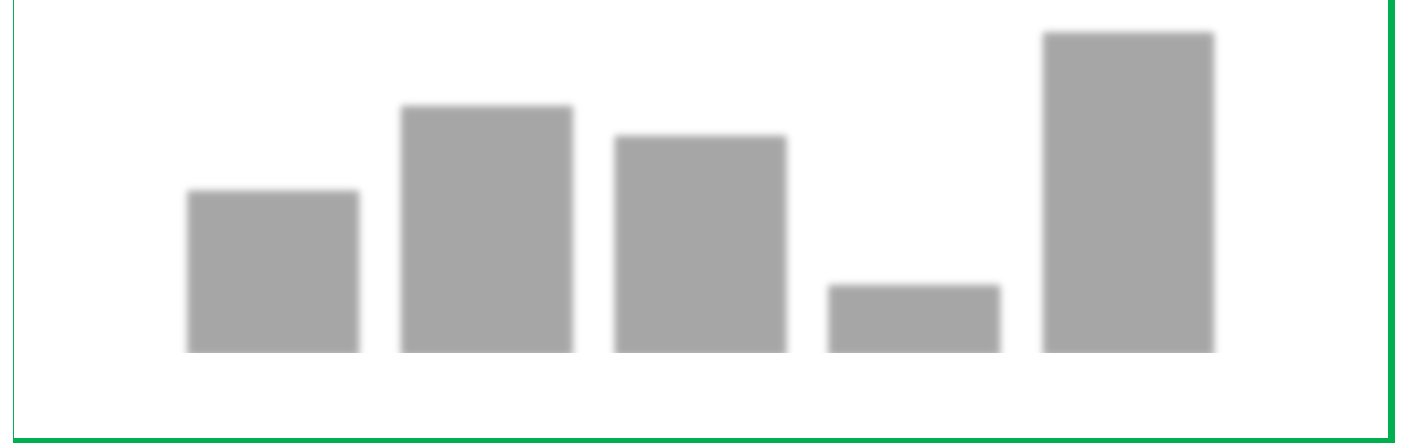

Rajah 1: Tujuan kunjungan ke pantai

\section{Cadangan dan merancang ke pantai}

Dalam kajian ini, keluarga turut ditanya siapa yang membuat cadangan dan merancang sesebuah percutian. Daripada hasil kajian, menunjukkan bahawa kepentingan suara seisi ahli keluarga iaitu gabungan pilihan ibu, bapa dan anak-anak amat ketara dalam perkara ini. Hampir kesemua ahli terlibat dalam menentukan destinasi pelancongan iaitu dengan nilai sebanyak 52.3\%. Akan tetapi, cadangan perseorangan iaitu daripada pihak ibu dan anak-anak juga tidak jauh ketinggalan. Berbeza pula dengan peranan bapa atau ahli keluarga lelaki masing-masing dalam peratusan yang kecil sahaja. Mengikut segmen keluarga pula, jelas menunjukkan bahawa tidak terdapat perbezaan yang ketara di antara ahli keluarga dengan ahli keluarga yang lain dalam aktiviti merancang dan membuat kunjungan ini. Dimana peranan cadangan ahli keluarga secara bersama (seisi keluarga) menunjukkan pilihan yang utama bagi setiap pelancong keluarga di Pantai Chenang. 


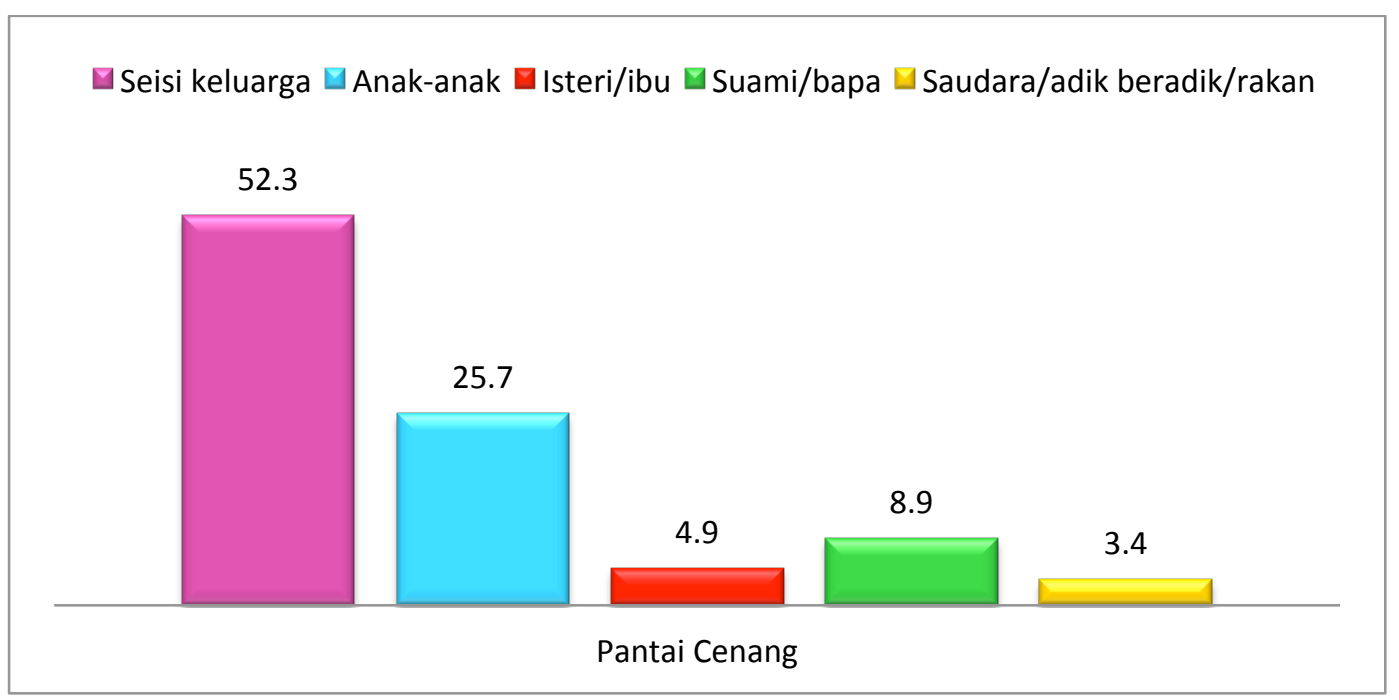

Rajah 2: Cadangan dan merancang ke pantai

\section{Siapa dibawa bersama ke pantai}

Siapa dibawa bersama ketika bercuti ke pantai tidak terkecuali mempamirkan bentuk aktiviti sebelum percutian di antara ahli keluarga. Penelitian secara mendalam siapa yang bersama dalam pelancong keluarga asas ataupun keluarga luasan, juga menunjukkan pengasingan berlaku di peringkat keluarga. Hampir separuh pelancong keluarga yang lebih ramai membuat kunjungan ke pantai pelancongan adalah dari kalangan keluarga asas penuh. Ini jelas menunjukkan bahawa kebanyakkan keluarga lebih senang menjalankan percutian mereka ke pantai bersama anak-anak jika dibandingkan dengan ahli keluarga yang lain iaitu dengan nilai sebanyak $70.1 \%$. Ini diikuti dengan seisi keluarga sebanyak $25.4 \%$. Manakala yang selebihnya adalah dari kategori suami isteri.

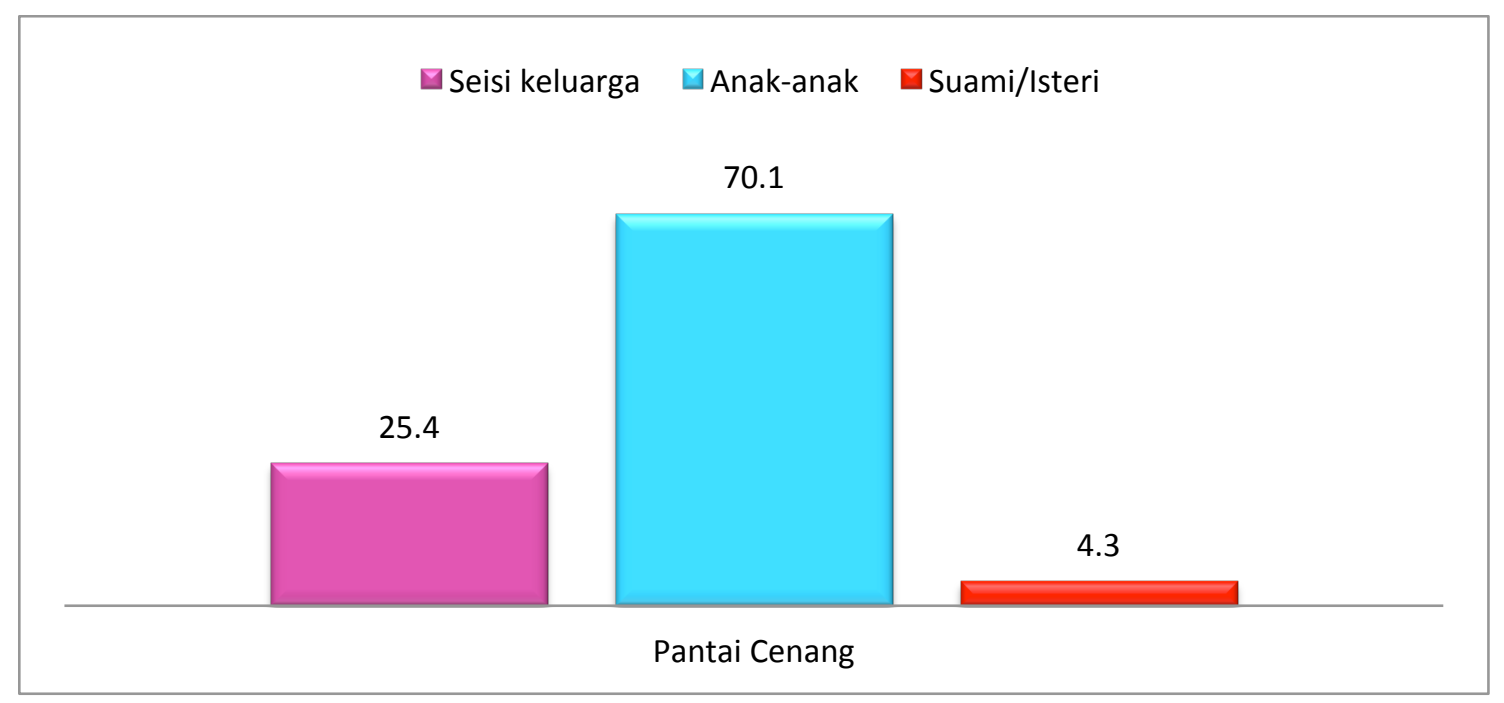

Rajah 3: Siapa dibawa bersama ke pantai

\section{Semasa di Pantai}

\section{Aktiviti utama ke pantai}

Berdasarkan jadual 2, sebanyak empat aktiviti utama dikenalpasti. Hampir separuh keluarga memilih aktiviti riadah merupakan aktiviti pilihan utama mereka ke pantai pelancongan tersebut dengan nilai 
sebanyak 97.4\%. Ini diikuti dengan aktiviti berehat dengan nilai sebanyak $64.3 \%$. Seterusnya aktiviti bersiar-siar dengan nilai sebanyak 50.9\%. Dan akhir sekali adalah aktiviti berkelah merupakan pilihan terakhir keluarga dengan nilai sebanyak $46.6 \%$.

Jadual 2: Aktiviti utama di pantai pelancongan

\begin{tabular}{lll}
\hline Aktiviti utama & Pantai Chenang & \\
\cline { 2 - 3 } & Bilangan & Peratus \\
\hline Berehat & 225 & 64.3 \\
Bersiar-siar & 178 & 50.9 \\
Perkelahan & 163 & 46.6 \\
Riadah & 341 & 97.4 \\
\hline
\end{tabular}

$\mathrm{N}$ bagi setiap aspek ialah 350 orang responden (100 peratus)

\section{Aktiviti sampingan}

Selain daripada melakukan aktiviti utama diatas, pelancong keluarga juga tidak melepaskan peluang untuk turut sama melakukan aktiviti sampingan atau sokongan yang lain bagi memenuhi masa terluang mereka ketika di pantai pelancongan. Aktiviti sampingan ini juga merujuk kepada aktiviti yang dilakukan oleh pelancong keluarga sepenuhnya di sekitar pantai pelancongan. Kebanyakkan aktiviti sampingan ini adalah melibatkan aktiviti rekreasi atau bersifat riadah di antara ahli keluarga. Terdapat empat kategori aktiviti sampingan yang telah dikenalpasti pengkaji iaitu aktiviti asas - mandi manda dan membina istana pasir, bermain layang-layang, menunggang kuda dan memancing, aktiviti sukan pantai - sukaneka pantai, bola tampar dan bola sepak pantai, aktiviti sukan air - banana boat, jet ski, parasailing dan kayak dan akhir sekali aktiviti santai - lepak/makan minum malam, bbq, menyaksikan konsert dan menyaksikan matahari terbenam.

Bagi aktiviti sampingan asas, aktiviti mandi manda dan membina istana pasir mencatat jumlah yang paling tinggi penglibatan keluarga jika dibandingkan dengan aktiviti sampingan asas yang lain dengan nilai sebanyak $49.1 \%$. Manakala bagi aktiviti sampingan sukan pantai pula menunjukkan aktiviti sukaneka adalah lebih tinggi penglibatannya berbanding sukan pantai yang lain dengan nilai sebanyak $26.3 \%$. Seterusnya aktiviti sampingan sukan air jenis banana boat pula mencatat nilai yang tinggi dari sukan air yang lain dengan nilai sebanyak 36.0\%. Akhir sekali aktiviti sampingan jenis santai menunjukkan aktiviti lepak dan makan minum sekitar Pantai Chenang mencatat nilai yang paling tinggi berbanding dengan aktiviti santai lain iatu sebanyak $18.3 \%$.

Jadual 3: Aktiviti sampingan

\begin{tabular}{llll}
\hline Kategori aktiviti & Aktiviti sampingan & \multicolumn{2}{c}{ Pantai Chenang } \\
\cline { 3 - 4 } & & Bilangan & Peratus \\
\hline Asas & Mandi manda dan membina & $\mathbf{1 7 2}$ & $\mathbf{4 9 . 1}$ \\
& $\begin{array}{l}\text { istana pasir } \\
\text { Bermain layang-layang }\end{array}$ & 0 & 0 \\
& $\begin{array}{l}\text { Menunggang kuda } \\
\text { Memancing }\end{array}$ & 2 & 00.6 \\
& & 88 & 25.1 \\
Sukan pantai & Sukaneka pantai & $\mathbf{9 2}$ & $\mathbf{2 6 . 3}$ \\
& Bola tampar pantai & 31 & 08.9 \\
& Bola sepak pantai & 26 & 07.4 \\
Sukan air/ & Banana boat & $\mathbf{1 2 6}$ & $\mathbf{3 6 . 0}$ \\
watersport & & & \\
& Jet ski & 99 & 28.3 \\
& Parasailing & 6 & 01.7 \\
& Kayak & 2 & 00.6 \\
\hline
\end{tabular}




\begin{tabular}{lll} 
Santai & $\mathbf{6 4}$ & $\mathbf{1 8 . 3}$ \\
& & \\
malam & 39 & 11.1 \\
Bbq & 26 & 07.4 \\
Menyaksikan konsert & 25 & 07.1 \\
\hline
\end{tabular}

\section{Makan dan minum di pantai}

Peratusan keluarga yang melakukan aktiviti makan dan minum di sekitar pantai pelancongan Chenang mencatat nilai sebanyak 95.4\%. Bagi jumlah yang selebihnya, pelancong keluarga lebih senang makan dan minum di luar kawasan pantai pelancongan seperti di sekitar bandar, di rumah-rumah persendirian atau hanya membawa makanan ringan atau bekalan. Manakala dari segi pemilihan tempat makan dan minum di Pantai Chenang menunjukkan sebanyak $28.0 \%$ pelancong keluarga lebih senang makan dan minum di restoren-restoren berbanding dengan tempat makan yang lain. Ini diikuti dengan makan minum di restoren segera sebanyak $26.3 \%$, makan dan minum secara berkelah atau membawa sendiri makanan dari rumah sebanyak $18.0 \%$, makan dan minum di sekitar hotel atau tempat penginapan pula mencatat jumlah sebanyak $15.7 \%$ akhir sekali gerai mencatat jumlah sebanyak $12.0 \%$ sahaja.

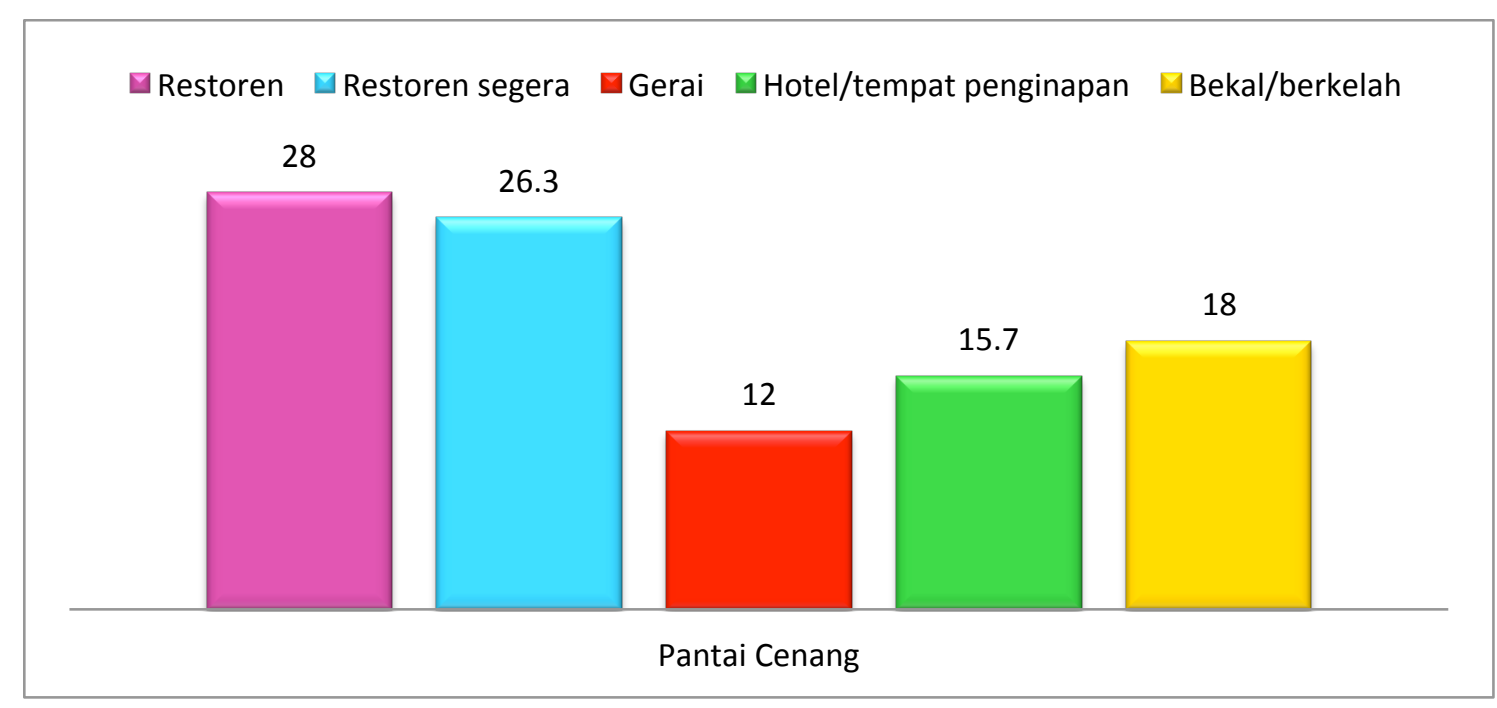

Rajah 4: Makan dan minum di pantai

\section{Membeli belah}

Sebagaimana aktiviti membeli-belah ini juga dikatakan salah satu aktiviti utama keluarga ketika di pantai pelancongan. Di Pantai Cenang, hampir 100 peratus responden melakukan aktiviti membeli belah ini iaitu dengan nilai sebanyak $90.9 \%$. Menurut pelancong keluarga, pilihan ini bergantung kepada destinasi yang mereka lawati. Jika di Langkawi umpamanya, boleh dikatakan bila-bila masa mereka boleh dan bekesempatan membeli-belah, tidak kira sama ada mengunjungi kawasan bebas cukai atau mengunjungi kawasan tertentu apatah lagi ketika mengunjungi gerai-gerai di sekitar Pantai Chenang. Tambahan lagi, Pantai Chenang antara destinasi pantai pelancongan yang sudah popular dengan aktiviti membeli-belah, jadi hampir separuh pelancong keluarga memilih untuk melakukan aktiviti membeli belah ketika di pantai pelancongan. 


\section{Pilihan penginapan di pantai}

Rata-rata pelancong keluarga di Pantai Cenang senang dan suka menginap di jenis penginapan hotel berbanding dengan jenis penginapan yang lain iaitu dengan nilai sebanyak $60.4 \%$. Ini diikuti dengan pilihan penginapan jenis resort di Pantai Cenang dengan nilai sebanyak $23.9 \%$ dan chalet $1.4 \%$. Mengikut segmen keluarga, golongan yang berpendapatan tinggi, didapati lebih memilih penginapan yang mahal diantara RM500 hingga lebih RM1000, iaitu jenis penginapan yang bertaraf empat atau lima bintang. Bagaimanapun golongan yang berpendapatan rendah di bawah RM1000 hingga RM1000-RM2000 memilih untuk menginap di tempat-tempat yang murah, adanya promosi, jauh dari pantai pelancongan atau menumpang di rumah saudara atau rakan. Hotel-hotel yang menghadap pantai lebih digemari berbanding hotel yang terletak di pusat bandar. Hotel-hotel pantai mencatat purata tempahan penginapan yang lebih tinggi, justeru, kadar sewa bilik hotel ditepi pantai lebih tinggi berbanding dengan hotel-hotel di bandar.

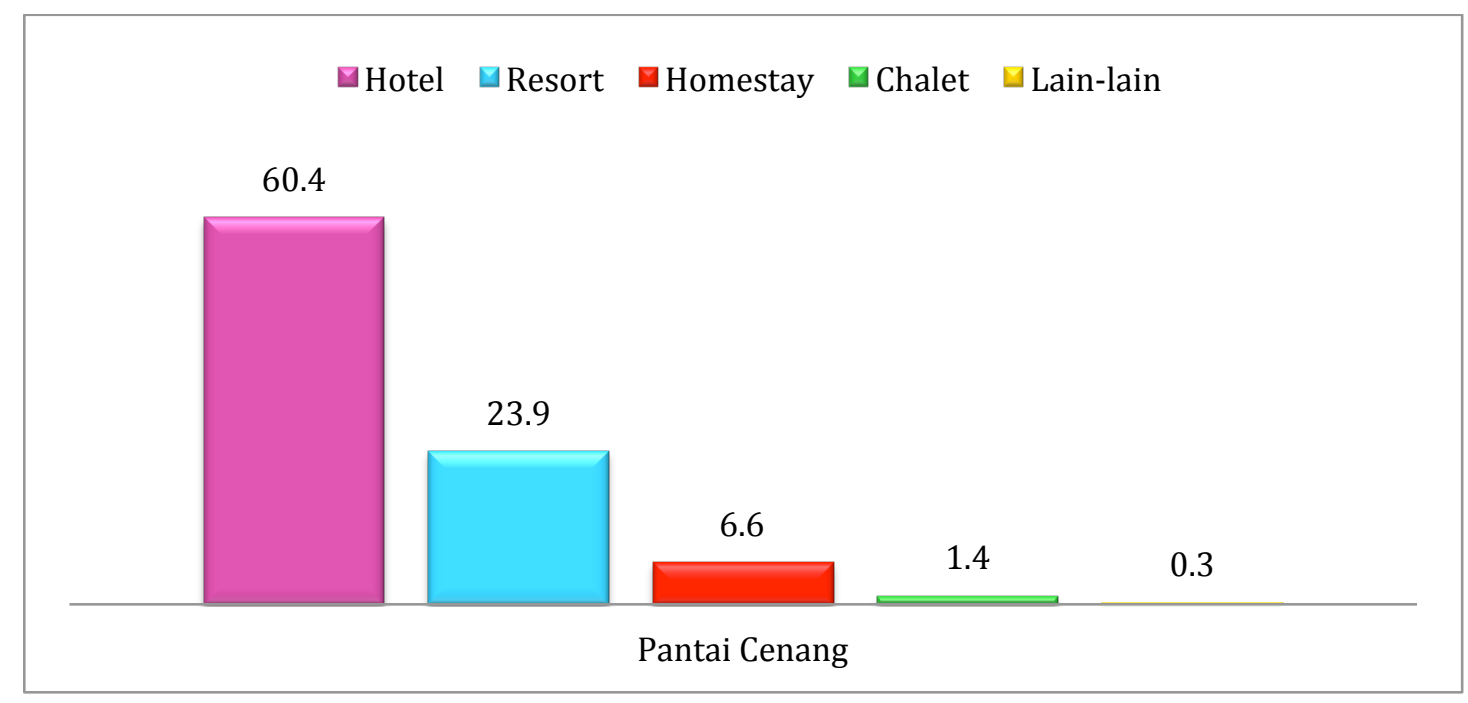

Rajah 5: Penginapan di pantai

\section{Mod pengangkutan ke/di destinasi}

Pilihan mod pengangkutan di sekitar pantai pelanconga Chenang jelas menunjukkan pengangkutan jenis sewa atau awam adalah menjadi pilihan utama mereka.

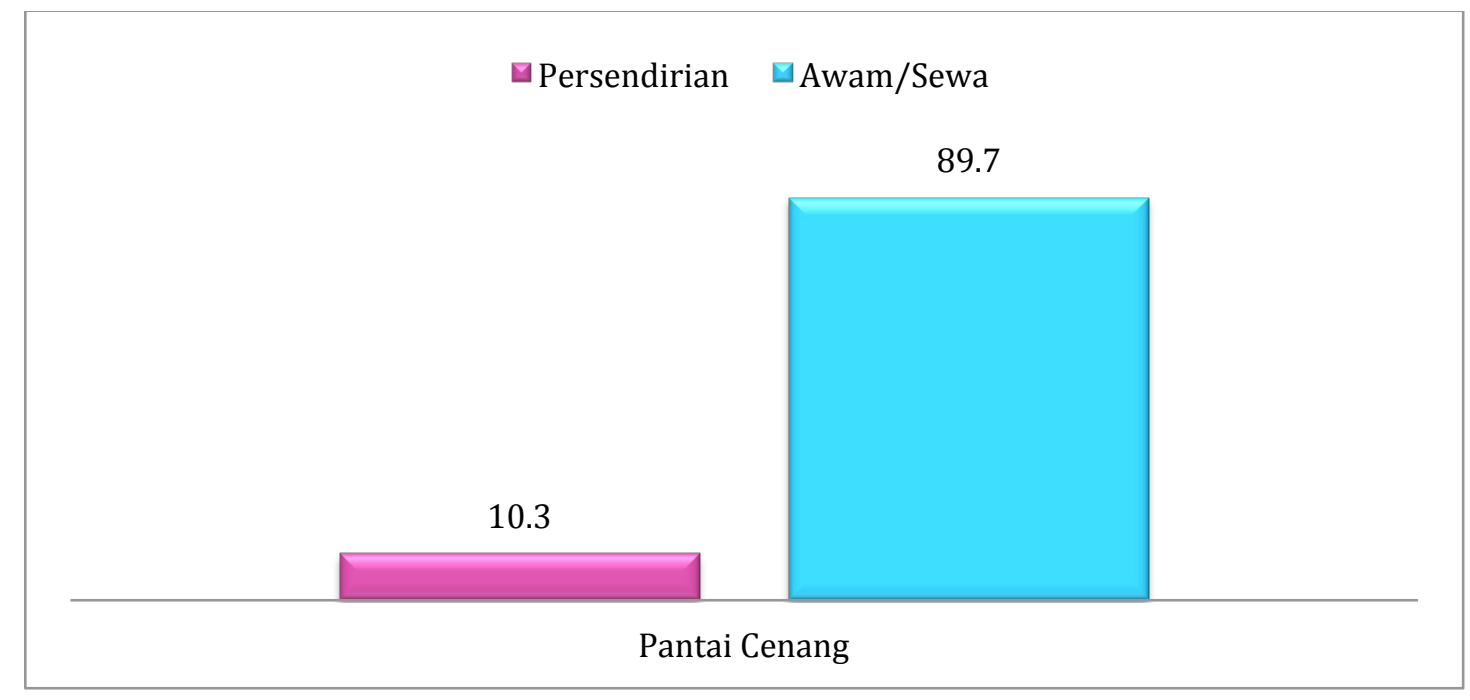

Rajah 6: Mod pengangkutan 
Hal ini kerana, kebanyakkan pelancong keluarga yang datang berkunjung ke Pantai Chenang adalah mereka yang datang dari Semenanjung Malaysia, sehubungan dengan itu, mereka terpaksa menggunakan kenderaan awam seperti kereta sewa, pesawat dan feri apabila mengunjungi Pantai Cenang kerana destinasi percutiannya yang sukar dan tidak dapat dihubungkan dengan kenderaan darat iaitu dengan nilai sebanyak $89.7 \%$.

\section{Selepas ke Pantai}

\section{Perbelanjaan keseluruhan selepas ke pantai}

Tidak terdapat perbezaan yang ketara dalam perbelanjaan dalam kalangan ahli keluarga di pantai pelancongan Chenang. Jika dilihat corak perbelanjaan pelancong keluarga mengikut pendapatan seperti jadual 4. Perbelanjaan yang lebih tinggi iaitu RM500 keatas banyak dilakukan oleh mereka yang berpendapatan RM1000-RM3000 hingga RM4000 keatas. Manakala bagi keluarga yang berpendapatan sederhana perbelanjaan mereka juga dalam cara yang sederhana iaitu diantara RM100 hingga RM500, pilihan perbelanjaan lebih daripada RM500-RM1000 hanya satu pertiga sahaja. Keluarga yang berpendapatan rendah pula jelas menunjukkan perbelanjaan mereka hanya berada di tahap yang paling rendah atau sedikit iaitu sekitar RM100-RM500 sahaja.

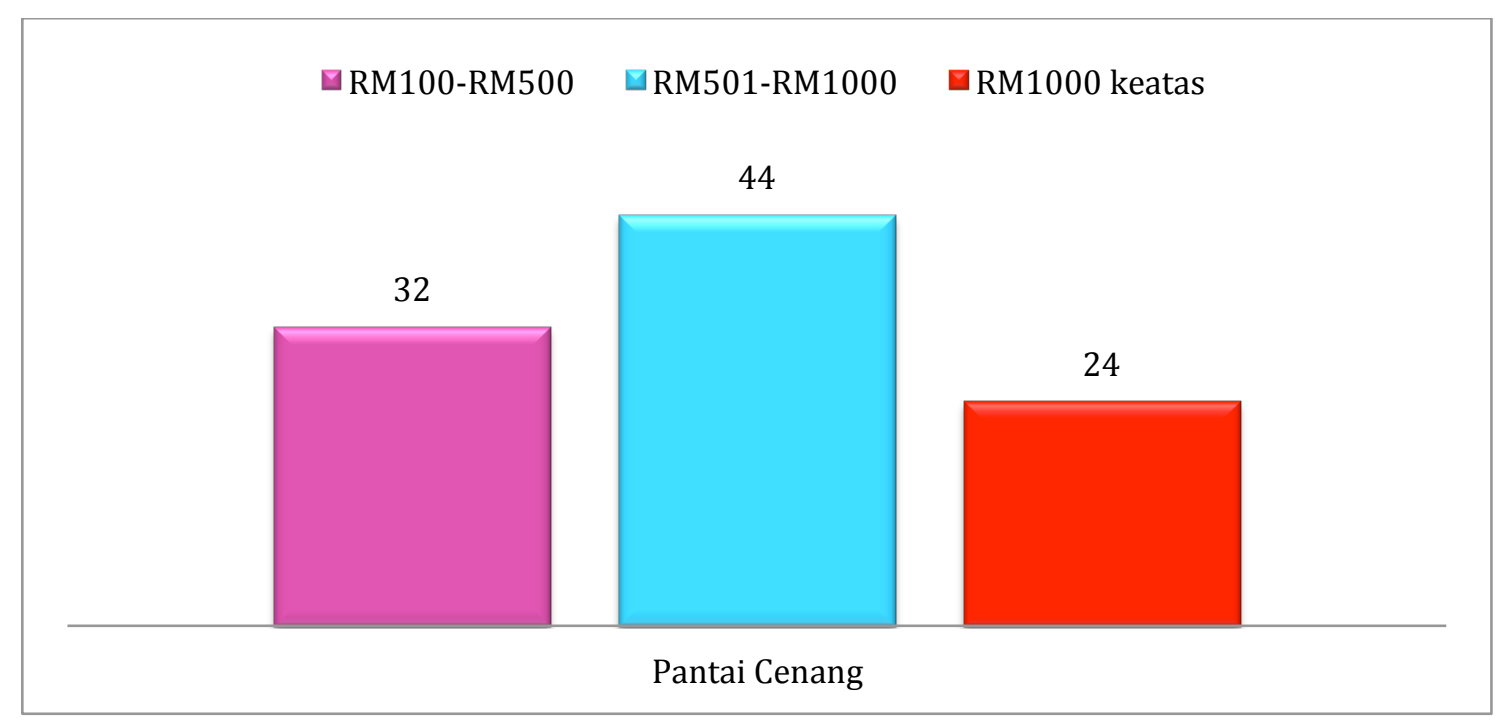

Rajah 7: Jumlah perbelanjaan selepas ke pantai

\section{Perbincangan}

Kajian empirikal ini telah menonjolkan beberapa ciri pelancong keluarga di pantai pelancongan. Antara ciri yang signifikan ialah kecenderungan bercuti dalam palbagai bentuk dan jenis kehidupan berkeluarga, iaitu dari keluarga muda hingga kepada keluarga matang, dari kalangan keluarga yang berpendapatan rendah sehingga berpendapatan tinggi. Dengan kata lain, tidak kira apa pun tahap kitaran dan situasi yang mereka alami, percutian bersama keluarga sudah menjadi satu 'kemestian'

Percutian bersama keluarga lebih mengarah kepada penggunaan masa bersama keluarga terdekat, terutamanya tiba musim cuti persekolah yang panjang atau untuk meraikan hari istimewa anggota sesebuah keluarga. Pengisian percutian adalah pelbagai, merangkumi aktiviti dari bermulanya merancang percutian sehinggalah kepada aktiviti di pantai pelancongan. Para pelancong keluarga lebih cenderung melakukan aktiviti yang mengarah kepada keperluan keluarga secara keseluruhan berbanding keperluan individu terutama ibu dan bapa. Tidak kira apa pun jenis keluarga, lazimnya mereka bercuti dalam konteks keperluan keluarga asas penuh, separa penuh dan keluarga luasan. Meskipun kekerapan bercuti agak tinggi, para pelancong keluarga tidak begitu ketara dalam 
menonjolkan ciri-ciri mengikut percutian kelas mewah atau kelas ekonomi semata-mata. Sebaliknya, mereka ketara mengamalkan percutian yang berasaskan sama rata terutamanya melibatkan aktiviti di pantai pelancongan.

Daripada kajian ini, jelas menunjukkan pelancong keluarga mempunyai peranan masing-masing dalam melakukan tiap aktiviti tidak kira untuk sebelum ke pantai, semasa di pantai sehinggalah selepas ke pantai. Peranan keluarga secara keseluruhan lebih tinggi daripada peranan mengikut individu tertentu sama ada ibu, bapa atau anak-anak. Mereka sama-sama memainkan peranan masing-masing dalam percutian pantai pelancongan ini.

\section{Kesimpulan}

Mengikut anti pati kajian ini menunjukkan ketiga-tiga kategori aktiviti iaitu sebelum, semasa dan selepas ke pantai pelancongan melibatkan secara keseluruhan ahli keluarga yang berkunjung di antara Pantai Chenang. Jika diamati, bermula dari awal percutian lagi iaitu sebelum ke pantai pelancongan. Ibu bapa dan anak-anak telah memainkan peranan mereka masing-masing. Rata-rata menunjukkan bahawa peranan keseluruhan keluarga dalam membuat keputusan ke pantai pelancongan telah mengatasi peranan ahli tertentu sahaja sama ada bapa, ibu atau anak-anak. Peranan ini jelas berlaku bukan sahaja di kediaman, iaitu dalam konteks persiapan dan perancangan percutian, tetapi juga berlaku semasa perjalanan, di pantai dan selepas di pantai. Pola pelancongan dalam kalangan pelancong keluarga menunjukkan kehadiran yang tinggi walaupun pelancong keluarga mempunyai perbezaan dari segi status ekonomi dan sosial, namun demikian mempunyai cirian yang hampir sama seperti menjalankan aktiviti pelancongan yang sama berserta dengan matlamat dan tujuan kehadiran ke pantai pelancongan adalah sama.

\section{Rujukan}

Ahmad Nazrin, Habibah Ahmad, Hamzah Jusoh, Mohd Yusof Hussain, Amriah Buang \& Sri Winarni Samsir. (2014). Pembentukan destinasi mesr pelancong berasaskan perspektif pelancong domestik. Malaysian Journal of Society and Space 10 (8): 1-12.

Alan Carr. (2011). Thematic review of family therapy journals 2010. Journal of Family Therapy 33: 429-447

Anuar ANA, Habibah A, Hamzah J, Hussain MY. (2012). The essential element underlying formation of tourist friendly destination concept. Journal of Management and Sustainability 2(1): 106-114.

Beioley, S. (2004). Meet the family-family holidays in the UK. Tourism Insights, UK.

Ceballos-Lascurain, H. (1987). The future of 'ecotourism'. Mexico Journal 13-14.

Debasis Sahoo. 2014. A Case Study On 'Beach-Tourism potential of Odisha. Journal of Kashmir for Tourism and Catering Technology 1(2).

Dwayne A. Baker \& John L. Crompton. (2000). Quality, satisfaction and behavioral Intentions. Annals of Tourism Research 27(3): 785-804.

E. Azzopardi \& R. Nash. (2013). Tourism Destination Competitiveness: Internal and External Comparisons of Malta and Cyprus. Tourism Analysis 18(5): 503-517.

Guiliano, G. (1997). Family structure and travel demand. Journal of Transport Geography. 5.1: 43.

Habibah Ahmad. (2007). Percutian famili Melayu bandar. Tesis phD. Universiti Kebangsaan Malaysia.

Habibah Ahmad. (2012). Percutian dan pembentukan keluarga bahagia. Fakulti Sains Sosial Dan Kemanusiaan, Universiti Kebangsaan Malaysia.

Khoshpakyants, A.V., \& Vidishcheva, E.V. (2010). Challenges of youth tourism. European researcher. (1): 101-103.

Malaysia. (2015). Laporan Tahunan Lembaga Pembangunan Langkawi 2015.

Martha Honey \& David Krantz. 2007. Global trends in Coastal Tourism. A nonprofit research organization Stanford University and Washington, DC.

Martha Honey \& Erick Vargas. (2007). Costa Rica's Pasific coast. 
DOI: https://doi.org/10.47405/mjssh.v5i1.351

Narimah Samat. (2010). Assessing Land Use Land Cover Changes in Langkawi Island: Towards Sustainable Urban Living. Malaysia Journal of Environmental Management 11(1) 2010.

Obrador, B. (2012). Budgets of organic and inorganic carbon in a Mediterranean coastal lagoon dominated by submerged vegetation. Estuarine, Coastal and Shelf Science 699 (1): 35-54.

Orams. M. (1999). The Concept of Ecotourism: Evolution and Trends. 2(3): 93-122

Proshanta Kumar Ghosh \& Debajit Datta. (2012). Coastal tourism and beach sustainability - An assessment of community perceptions in Kovalam, India. Malaysia Journal of Society 8(7): 7587.

Sufahani, S.F, et al. (2013). An Analysis of International Tourist Behaviour Toward Tourism Sector in Kelantan. Prosiding Seminar Kebangsaan Aplikasi Sains and Matematik 2013 (SKASM2013) Batu Pahat, Johor, 29-30 October 2013, pp. 151-163.

Swarbrooke J. (1995). The Development and Management of Visitor Attractions. Butterworth Heinemann, London.

Syafrina I., Ibrahim K.,\& Joy J.P. (2000). Pantai: sumber geopelancongan berpotensi. Geological Society of Malaysia Annual Geological Conference.

Yesawich, P.C., Stowe, S., \& Robert, C.L. (2007). Marketing Leadership in Hospitality and Tourism: Strategies and Tactics for Competitive Advantage.

United Nation World Tourism Organization. (2016) 